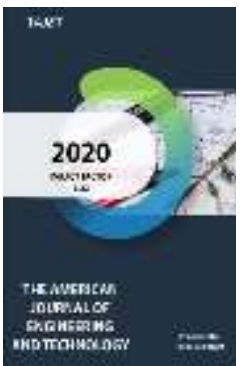

\title{
The Pecularities Of Automatic Headlights
}

\author{
Donyorbek Dilshodovich Alijanov \\ $\mathrm{PhD}$ In Technical Sciences Andijan Machine-Building Institute, Uzbekistan
}

Utkirbek Akramjonovich Axmadaliyev

Senior Teacher Andijan Machine-Building Institute, Uzbekistan

\begin{abstract}
Journal Website: http://usajournalshub.c om/index,php/tajet

Copyright: Original content from this work may be used under the terms of the creative commons attributes 4.0 licence.
\end{abstract}

\section{ABSTRACT}

Today, the types of vehicles and their functions are increasing, creating favorable conditions for humans. Sensors play an important role in performing functions such as driving, tracking, traffic regulation. The main function of sensors is to receive incoming information and transmit it to other forms of data. For example, we can take photoelectric sensors. Photoelectric sensors receive incoming light current and transmit information in the form of electrical voltage.

\section{KEYWORDS}

Automatic, APV (Anomalous photo voltage ), photo sensor, headlight, optocoupler, vehicle, lighting system, high-voltage, detector, car.

\section{INTRODUCTION}

The use of photoelectric sensors is being developed to automate the lighting system in the latest generation vehicles. If the vehicle lighting system on the one hand is of great importance in ensuring traffic safety, then on the other hand it also performs the task of creating certain amenities for drivers and passengers. It also causes discomfort for a motorist walking in the opposite direction while driving. The increase in the number of vehicles and their behavior leads to a sharp increase in the number of adverse traffic events. According to the State Network of Automobile Control, over $60 \%$ of these road accidents 
The American Journal of Engineering and Technology

(ISSN - 2689-0984)

Published: October 21, 2020 | Pages: 13-16

occur in conditions where vision is poor (i.e. at night, fog, rain).

\section{MAIN PART}

At present, in order to ensure traffic safety and not attract the attention of motorists, it is desirable to install more types of signaling devices, reducing the number of types of indicating instrumentation.

Traffic safety of vehicles, especially at night and in cases when vision is poor, largely depends on the condition and parameters of the lighting equipment. The headlights of the car must meet the requirements of two opposite sides: they must well illuminate the road in front of the car and not dazzle the driver of the vehicle coming from the opposite side. Glare from an approaching driver's car under headlights is a very serious problem that is directly related to driving safety. Currently, this task is solved using two modes, namely high and low beam headlights.
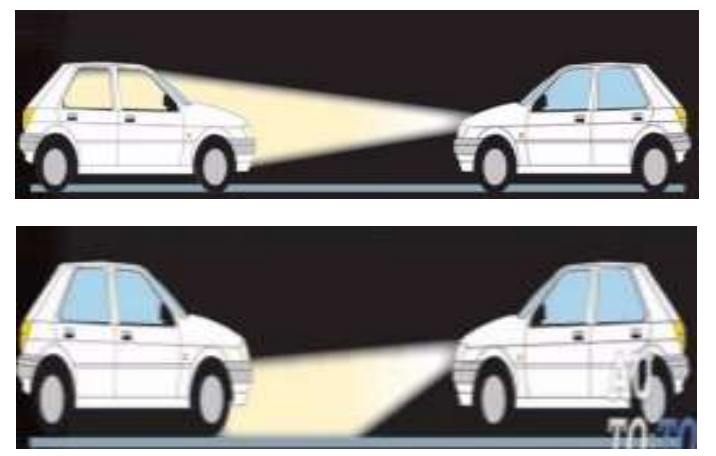

Figure 1. The movement of cars moving in

opposite directions to each other.

The high beam headlamp system is designed to illuminate the road in front of a vehicle without a vehicle on the opposite side. The nearest lighting system is used when the road in front of the vehicle passes through residential and illuminated areas as the vehicle approaches.

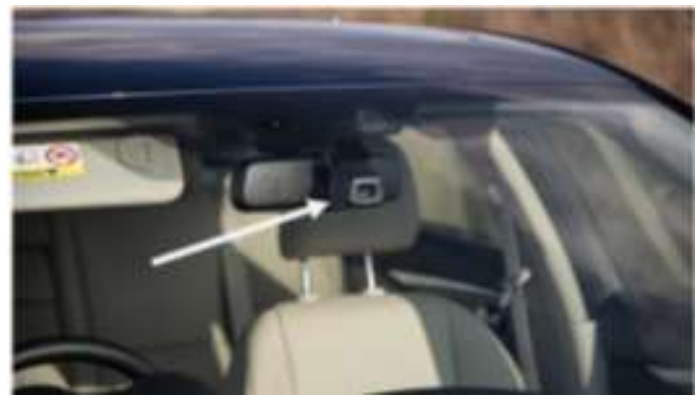

Figure 2. Photosensitive element.

When two cars are moving in opposite directions, high beams temporarily reduce the ability to see in both drivers (Picture 1.). A photo sensor installed on the front window of the car automatically turns off the high beam headlights and turns on the low beam. We offer an APV (Anomalous photo voltage) receiver instead of a photo sensor. The difference between APV elements and traditional photoconductors is that they have the property of an optical light-receiving generator and are an electric generator operating at the expense of a light beam, that is, the APV element directly produces a high-voltage photoconductor and operates at the same voltage.

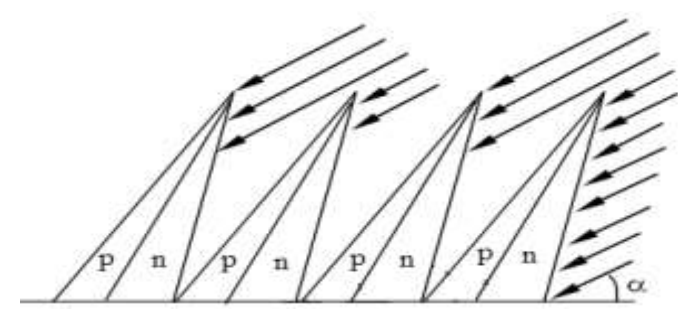

Figure 3. Structural view of film

\section{illumination with p-n transitions.}

In optoelectronic devices based on a transmitter and a receiver, the APV receiver is used as a primary converter that converts an optical signal into an electrical one. It transmits information about the magnitude of the resulting electrical signal, recorded in the form of a voltage or a circuit diagram, separating the parameters and processing them. Thus, the converted measured value signal is transmitted to the reading device [1]. 
The principle of operation of any optocoupler is based on the conversion of radiation from an electrical signal to an optical one, followed by the conversion of optical radiation into an electric current or voltage. The physical meaning of the optocoupler is that the photon is used as a carrier of information and provides a very high optical isolation of the input and output of the optocoupler. Currently, the task is to create an optocoupler based on APV - films similar in their properties to optocouplers "emitter - photodiode", "emitter - photocell", etc. An optocoupler based on APV films is characterized by the fact that very weak signals are amplified with the help of APN films. In addition, in an optocoupler with direct optical communication, operating on the basis of the APV effect, the amplification of the signal of the optical radiation receiver (OPI) is removed [2-5].

In optoelectronic systems, the fact that elementary optical detectors of APV do not require an electric source when using an electric source makes it possible to operate APV sensors in an autonomous state [4-7].

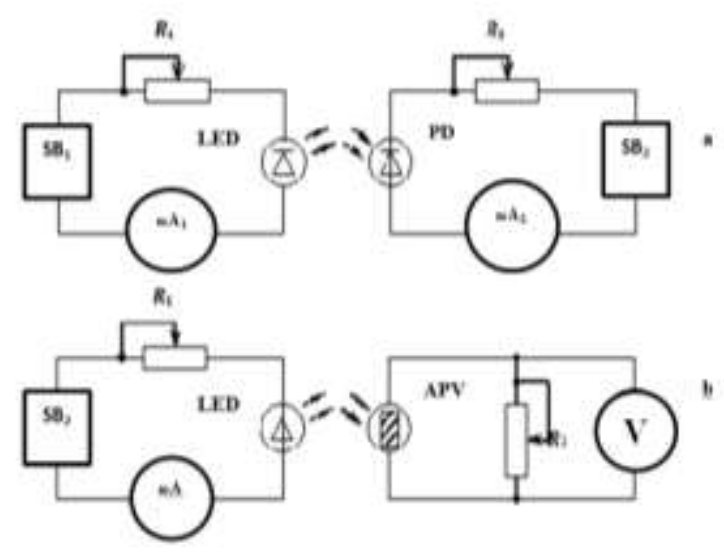

Figure 4. Optocoupler

$$
\begin{aligned}
& a \text { - LED - photodiode ; } b \text { - LED - APV } \\
& \text { receiver. }
\end{aligned}
$$

\section{Main technical data of APV receiver}

\author{
Sensitivity at IV = 1 lx, $\quad 5 \mathrm{~V}$ \\ Internal resistance, Ohm ... ... 10 $10^{14}$ \\ Speed, $\mathrm{s} \quad 1$ \\ Durability, h, not less ......... 10000
}

\section{CONCLUSION}

Compared to other photosensors, the sensitivity of the APV receiver is $\quad 20-30 \%$ higher; it does not need to be connected to an electrical circuit for operation. The same feature is the prospect of using the APV receiver as a photosensor in automated systems.

\section{REFERENCES}

1. Raximov N.R., Seryoznov A.N. AFN-plenki i ix primenenie. -Novosibirsk, 2005.-65s.

2. N.R. Raximov, D.D Alijanov, V.A. Jmudb. Perspektivi primeneniya AFN - priemnika dlya razrabotki optoelektronnoy informatsionno izmeritelnoy sistemi. // Nauchniy vestnik NGTU -2014g.

3. Raximov N.R., Ushakov O.K. Optoelektronnie datchiki na osnove AFN-effekta. Novosibirsk: SGGA, 2009 g. 148 str.

4. Razrabotka optoelektronnix datchikov na osnove AFN-plenok iz poluprovodnikovix soedineniy / D.D. Alijanov, N.R. Raximov, V.A. Jmud // Sbornik nauchnix trudov NGTU. - 2012. - №2(68).

5. Osobennosti polucheniya fotochuvstvitelnix plenok $\mathrm{s}$ anomalnim fotonapryajeniem // Alijanov D.D.//Avtomatika i programmnaya injeneriya. - 2013. - № 3 (5). - S. 81-84.

6. Koordinatno-chuvstvitelnie priemniki opticheskogo izlucheniya na osnove poluprovodnikovix plenok $\mathrm{S}$ anomalnim fotonapryajeniem / N.R. Raximov, A.N. 
The American Journal of Engineering and Technology (ISSN - 2689-0984)

Published: October 21, 2020 | Pages: 13-16

Doi: https://doi.org/10.37547/tajet/Volume02Issue10-03

Sereznov, B.N. Raximov, D.D. Alijanov // 2016

13th International Scientific-Technical

Conference APEIE.

7. Coordinate-Sensitive Receiver / D.D. Alijanov, Bakhranov Sh.K. // International Journal of Research Studies in Electrical and Electronics Engineering(IJRSEEE) Volume 5, Issue 4, 2019, PP 17-22. 